\title{
Red blood cell and plasma glutathione peroxidase activities and sele- nium concentration in patients with chronic kidney disease: A review
}

\author{
Bronisław A. Zachara ${ }^{1,2 \bowtie}$, Jolanta Gromadzińska ${ }^{1}$, Wojciech Wąsowicz ${ }^{1}$ and \\ Zbigniew Zbróg 3 \\ ${ }^{1}$ Department of Toxicology and Carcinogenesis, Nofer Institute of Occupational Medicine, Łódź, Poland; ${ }^{2}$ Higher \\ School of Health Science, Bydgoszcz, Poland; ${ }^{3}$ Avitum Dialysis Center, tódź, Poland; \\ 凶bronzach@yahoo.com
}

Received: 12 October, 2006; revised: 23 November, 2006; accepted: 07 December, 2006

available on-line: 11 December, 2006

\begin{abstract}
The metabolism of oxygen in aerobic organisms leads to generation of reactive oxygen species (ROS). These entities are able to oxidize almost all classes of macromolecules, including proteins, lipids and nucleic acids. The physiological level of ROS is usually regulated by antioxidant defense mechanisms. There are at least three groups of antioxidant enzymes: superoxide dismutases, catalases and glutathione peroxidases (GSH-Pxs) which neutralize ROS. The trace elements (copper, zinc and selenium) bound to the active sites of the above listed enzymes play an important role in the antioxidant defense system. In mammals, a major function of selenium (Se) and Se-dependent GSH-Pxs is to protect cells from oxidative stress. Selenium concentrations and GSH-Px activities are altered in blood components of chronic kidney disease (CKD) patients. The Se level is frequently lower than in healthy subjects and the concentration very often decreases gradually with advancing stage of the disease. Studies on red cell GSH-Px activity in CKD patients reported its values significantly lower, significantly higher and lower or higher, but not significantly as compared with healthy subjects. On the other hand, all authors who studied plasma GSH-Px activity have shown significantly lower values than in healthy subjects. The degree of the reduction decreases gradually with the progression of the disease. High inverse correlations were seen between plasma GSH-Px activity and creatinine level. A gradual decrease in plasma GSH-Px activity in CKD patients is due to the fact that this enzyme is synthesized predominantly in the kidney and thus the impairment of this organ is the cause of the enzyme's lower activity. Se supplementation to CKD patients has a slightly positive effect in the incipient stage of the disease, but usually no effect was observed in end-stage CKD. Presently, kidney transplantation is the only treatment that may restore plasma Se level and GSH-Px activity in patients suffering from end-stage CKD. A few studies have shown that in kidney recipients, plasma Se concentration and GSH-Px activity are restored to normal values within a period of 2 weeks to 3 months following surgery and thus it can be acknowledged that Se supplementation to those patients has a positive effect on plasma GSH-Px activity.
\end{abstract}

Keywords: antioxidants, chronic kidney disease, glutathione peroxidase, hemodialysis, kidney transplantation, plasma, selenium

\section{INTRODUCTION}

In normal physiological conditions, the metabolism of oxygen in aerobic organisms leads to the generation of dangerous and very reactive compounds, known as free radicals or reactive oxygen species (ROS) (Meier, 2001; Lim et al., 2002), including superoxide radical $\left(\mathrm{O}_{2}{ }^{--}\right)$and hydroxyl radical $\left(\mathrm{OH}^{\circ}\right)$ (Fantel, 1996; Castro \& Freeman, 2001; Young \& Woodside, 2001). Some authors consider hydrogen peroxide $\left(\mathrm{H}_{2} \mathrm{O}_{2}\right)$ as a free radical, although it is not one (Castro \& Freeman, 2001), as it can easily

Abbreviations: CAPD, continuous ambulatory peritoneal dialysis; $\mathrm{CAR}$, clinical acute rejection; Cat, catalase; CKD, chronic kidney disease; CMV, cytomegalovirus; GSH, glutathione; GSH-Px, glutathione peroxidase; HD, hemodialysis; MDA, malonyldialdehyde; $\mathrm{ROS}$, reactive oxygen species; $\mathrm{ROH}$, organic alcohol; $\mathrm{ROOH}$, organic hydroperoxide; Se, selenium; Sec, selenocysteine; SeMet, selenomethionine; SOD, superoxide dismutase; TMSe, trimethylselenonium ion. 
cross cell membranes and in the presence of transition metals (e.g. iron or copper) can be reduced to $\mathrm{OH}^{\bullet}$, the strongest oxidant generated in biological systems (Jamieson, 1989; Fantel, 1996). Free radicals are able to oxidize almost all classes of biologically important macromolecules, including proteins, lipids and nucleic acids (Halliwell \& Gutteridge, 1989). The physiological level of oxidants is usually regulated by antioxidant defense mechanisms, both endogenous and exogenous, which control the flux of ROS through specific scavenger reactions and detoxification pathways (Galli et al., 1999; Baynes \& Thorpe, 1999). An elevated level of ROS and/or reduced antioxidant activity result in increased oxidative stress, which has been implicated in the pathology of several diseases, such as tumor development, viral expression (HIV, AIDS), neurological diseases (Alzheimer's, Parkinson's), diabetes mellitus, atherosclerosis, hypertension, and chronic kidney disease (CKD) (Marx, 1987; Meier, 2001). The antioxidant defense system can be divided into two major groups: endogenous mechanisms (mainly enzymes) and small, mostly exogenous, molecular compounds, acting as free radical scavengers (Saito \& Takahashi, 2000; Stanczyk et al., 2005).

In aerobic organisms several enzymes are involved in scavenging free radicals: superoxide dismutases (SOD; EC 1.15.1.1), catalases (Cat; EC 1.11.1.6), glutathione peroxidases (GSH-Px; EC 1.11.1.9) (Joseph, 1995; Grignard et al., 2005) and probably selenoprotein P (Saito \& Takahashi, 2000; Burk \& Hill, 2005). The reactions catalyzed by these enzymes are presented in Fig. 1. (Young \& Woodside, 2001).

In mammalian tissues, there are at least three distinct superoxide dismutase isoenzymes, including one manganese form (Mn-SOD) present in the mitochondrial matrix and two copper and zinc forms $(\mathrm{Cu}, \mathrm{Zn}-\mathrm{SOD})$, one of which is in the cytosol and the other in various extracellular fluids (Fantel, 1996; Young \& Woodwide, 2001). Superoxide dismutases play a key role in catalyzing the dismutation of $\mathrm{O}_{2}{ }^{-}$ to $\mathrm{O}_{2}$ and $\mathrm{H}_{2} \mathrm{O}_{2}$. Catalase or GSH-Px must then re-

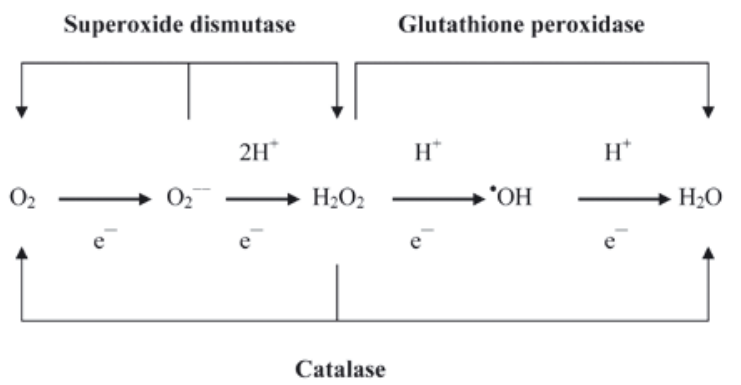

Figure 1. Participation of antioxidant enzymes in neutralization of reactive oxidative species in mammalian tissues.

Taken from Young \& Woodside, 2001. move the hydrogen peroxide formed. In the presence of transition metals, $\mathrm{H}_{2} \mathrm{O}_{2}$ can be reduced (in the metal-catalyzed Haber-Weiss reaction) to the extremely reactive ${ }^{\circ} \mathrm{OH}$ (Fantel, 1996). In many tissues, catalase activity, largely localized to peroxisomes, is very low and frequently not available for decomposition of $\mathrm{H}_{2} \mathrm{O}_{2}$. Therefore, in most tissues, $\mathrm{H}_{2} \mathrm{O}_{2}$ decomposition is obtained by GSH-Px (Joseph, 1995). This enzyme catalyzes the reduction of $\mathrm{H}_{2} \mathrm{O}_{2}$ and a wide range of organic hydroperoxides ( $\mathrm{ROOH}$ ) to water and corresponding alcohols $(\mathrm{ROH})$, respectively. They are very specific for glutathione (GSH) as the reducing substrate (Patching \& Gardiner, 1999; Arthur, 2000). The enzymes involved in the scavenging of free radicals catalyze the following reactions:
1) $\mathrm{O}_{2}^{\cdot-}+\mathrm{O}_{2}^{\cdot-}+2 \mathrm{H}^{+}$

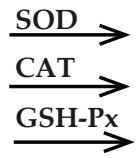
$\mathrm{H}_{2} \mathrm{O}_{2}+\mathrm{O}_{2}$
2) $\mathrm{H}_{2} \mathrm{O}_{2}+\mathrm{H}_{2} \mathrm{O}_{2}$
3) $\mathrm{ROOH}\left(\mathrm{H}_{2} \mathrm{O}_{2}\right)+2 \mathrm{GSH}$
$2 \mathrm{H}_{2} \mathrm{O}+\mathrm{O}_{2}$
$\mathrm{ROH}\left(\mathrm{H}_{2} \mathrm{O}\right)+$ $\mathrm{H}_{2} \mathrm{O}+$ GSSG

\section{SELENIUM IN BLOOD COMPONENTS AND IN URINE}

\section{Selenium in blood components and Se metabolites in urine of healthy individuals}

Kidneys play an important role in the homeostasis of selenium (Se) (Lockitch, 1989; Neve, 1991). When Se is consumed at rates close to the human nutritional requirement, its highest level is found in kidneys and then in the liver (Combs \& Combs, 1984). It has been shown that the amount of Se in the kidney, calculated per wet mass, is 1.4 to about 3 times higher than in the liver and 6.6 to 10 times higher than in skeletal muscles (Zachara et al., 2001b). The Se level in tissues/organs depends on its daily intake, the chemical form of ingested Se and probably on other unknown factors (Lockitch, 1989; Alaejos \& Romero, 1993). Thus the tissue Se level in people from seleniferous regions is much higher than in those living in low Se areas (Zachara et al., 2001b).

The predominant route of Se excretion in the healthy human is urine and feces (Robberecht \& Deelstra, 1984; Alaejos \& Romero, 1993). Se losses in urine represent $50-70 \%$ of the ingested element. At high or low levels of intake, more or less Se is excreted with urine. Yang et al. (1989) studied the relation between Se intake and 24-h urinary Se excretion in Chinese living in regions with low $(66.3 \mu \mathrm{g})$, medium $(196 \mu \mathrm{g})$ and high $(1338 \mu \mathrm{g})$ daily dietary Se intake and found a linear, highly significant correlation $(\mathrm{r}=0.886$; $P<0.001)$ between those parame- 
ters. People consuming 20 times more of Se (low vs. high Se region) excreted with urine 22 times more of the element. The percentage of Se excretion increased progressively with increasing Se supply. In individuals supplemented with 55, 135 and $215 \mu \mathrm{g}$ Se/day, total losses of this element with urine averaged 43,55 and $64 \%$ of ingested Se (Van der Torre et al., 1991; Alaejos \& Romero, 1993).

In 1969, Byard was the first to identify a urinary Se metabolite as trimethylselenonium ion (TMSe). Almost at the same time Palmer et al. (1969; 1970) identified TMSe as the major Se metabolite in rat urine. These authors have shown that TMSe is a common urinary metabolite from all tested Se sources and constituted $20-50 \%$ of the urinary Se. The TMSe level in urine has been generally thought to increase when Se exposure is above the nutritional requirement. This Se metabolite was later found in human urine (cf. Francesconi \& Pannier, 2004). Se metabolism in mammals and its transformation into methylated forms are shown in Fig. 2. (Medina et al., 2001).

Recent analytical advances based on HPLC separations coupled with atomic and molecular mass spectrometric detection have provided new insights into Se metabolites in urine (Francesconi, 2006). In particular, novel Se-containing selenosugars are now known to be major urinary metabolites in humans and in rats, and TMSe is now considered to be a less significant metabolite (Francesconi \& Pannier, 2004; Suzuki et al., 2005). Among them a metabolite called selenosugar 2 (methyl-2-acetamido-2-deoxy-1 seleno$\beta$-D-galactopyranoside) has been identified (Kobayashi et al., 2002; Francesconi \& Pannier, 2004; Suzu-

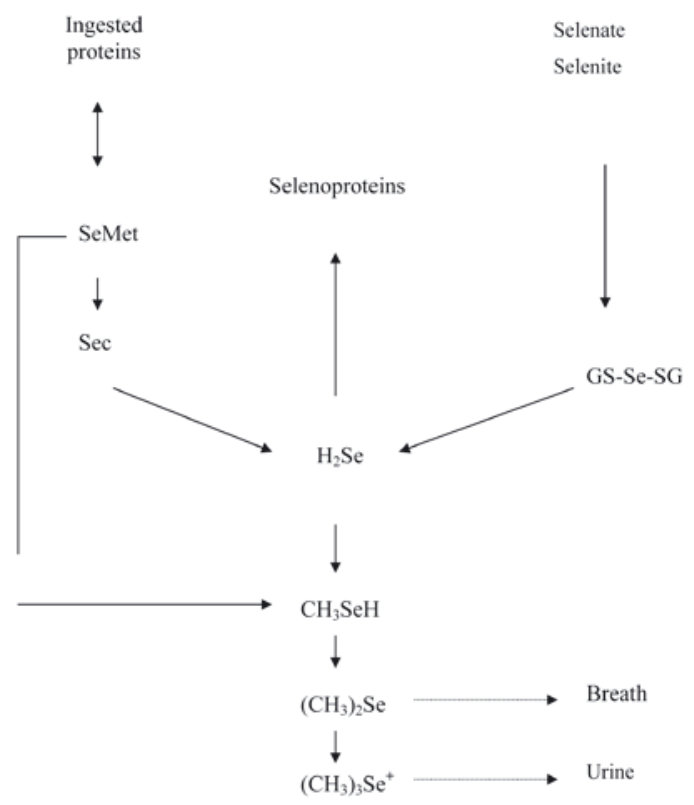

Figure 2. Selenium metabolism in mammals.

Taken from Medina et al., 2001, modified. Sec, selenocysteine. ki, 2005; Suzuki et al., 2005). Two other selenosugars ( 1 and 3 ) have been identified in lower levels (Kobayashi et al., 2002; Francesconi \& Pannier, 2004).

Suzuki et al. (2005) have shown that in young rats supplied with the required to low toxic levels of Se, selenosugar was always the major urinary metabolite. TMSe starts to increase in urine with excessive Se intake. In adult rats, TMSe is present only as a minor metabolite and thus it cannot be a marker of excessive Se intake. Kuehnelt et al. (2006) have recently shown that in volunteers supplemented with $200 \mu \mathrm{g}$ Se as selenite, TMSe was present in trace amounts (0.02 to $0.28 \mu \mathrm{g} \mathrm{Se} / \mathrm{L}$; equivalent to $1-$ $5 \%$ Se in urine), while selenosugars ranged from 4.6 to $15 \mu \mathrm{g} \mathrm{Se} / \mathrm{L}$ (22 to $53 \%$ of Se in urine). The precise mechanisms by which diverse nutritional selenocompounds are transferred to common intermediate selenide, then selenide to selenosugars and TMSe, are not known (Suzuki, 2006).

\section{Selenium in blood components of chronic kidney disease patients}

Although some investigators did not find any difference between CKD patients and healthy subjects regarding whole blood or plasma Se concentrations (Tsukamoto et al., 1980; Lockitch, 1989; Milly et al., 1992), significantly lower values have been more often shown in the former group (Dworkin et al., 1987; Foote et al., 1987; Richard et al., 1991; Girelli et al., 1993; Ceballos-Picot et al., 1996; Yoshimura et al., 1996; Vural et al., 2005; Zachara et al., 2000a; 2001c). Several authors have found that in non-dialyzed CKD patients the overall plasma Se concentration from incipient to the end-stage of the disease is by $12.5-44.1 \%$ lower than in healthy subjects (Kallistratos et al., 1985; Richard et al., 1991; Girelli et al., 1993; Loughrey et al., 1994; Ceballos-Picot et al., 1996; Zachara et al., 2000a). Zachara et al. (2000b) reveal that in the early stage of the disease, Se concentration in whole blood and plasma does not significantly differ from the value of the control group. Similar results have been presented by Ceballos-Picot et al. (1996). Along with the progression of the kidney impairment, Se concentration decreases in whole blood and plasma. This was particularly evident in the end-stage of the disease, where Se concentration in whole blood and plasma was lower by 47 and 50\%, respectively $(P<0.0001)$ as compared with the control group (Zachara et al., 2000b). In the entire group of CKD patients, weak but significant negative correlations were found between plasma Se and plasma creatinine levels $(\mathrm{r}=-0.380 ; P<0.0001)$ as well as between plasma Se and plasma urea nitrogen levels $(\mathrm{r}=-0.348 ; P<0.0001)$ (Zachara et al., 2004b). Higher negative correlations were found by Ceballos-Picot et al. (1996) and Yoshimura et al. (1996). 
In patients on hemodialysis (HD), plasma Se concentration was also significantly lower than in healthy subjects, and the degree of the reduction was very often similar to that in non-dialyzed patients (Kallistratos et al., 1985; Dworkin et al., 1987; Foote et al., 1987; Kuroda et al., 1988; Saint-Georges et al., 1989; Richard et al., 1991; Girelli et al., 1993; Bonomini et al., 1996; Ceballos-Picot et al., 1996; Lachili et al., 1996; Yoshimura et al., 1996; Zachara et al., 2000a). Dworkin et al. (1987) have shown that in patients undergoing continuous ambulatory peritoneal dialysis (CAPD), Se concentration in blood components was significantly lower than in HD patients. The lower blood Se level in CAPD patients probably reflects a greater protein leak across the peritoneal membrane as compared with HD patients (Dworkin et al., 1987). However, Girelli et al. (1993) have not found any difference between plasma Se concentration in CAPD and HD patients, while Zima et al. (1998) found this concentration higher in CAPD than in HD patients. Further studies on a larger group of patients are required to elucidate the discrepancies.

Several authors measured the effect of dialysis on the Se level in blood components. It has been shown that after dialysis, Se concentration in plas$\mathrm{ma} /$ serum increases by $5.5-20.3 \%$, however, in some studies this increment was insignificant (Dworkin et al., 1987; Bonomini et al., 1996), while in others it was statistically proved (Milly et al., 1992; Lachili et al., 1996). Surprisingly, the measurement of Se concentration in whole blood did not reveal any differences (Dworkin et al., 1987; Milly et al., 1992), which means that the observed differences mostly apply to Se present in serum/plasma, but probably not in red blood cells. It is well known that about $95 \%$ of Se present in plasma is found in proteins (MarchanteGayon et al., 1996). These compounds, being macromolecules, do not penetrate membranes and thus cannot be removed from the organism during HD.

It has been experimentally documented that Se present in plasma is incorporated into GSH-Px and selenoprotein $\mathrm{P}$ as selenocysteine (SeCys), or bound to albumin in the form of selenomethionine (SeMet) (Deagan et al., 1993). A small amount of Se is present in micromolecules with unknown structure and function (Marchante-Gayon et al., 1996). Deagan et al. (1993) showed that in human plasma, irrespective of Se concentration (from 21 to $162 \mathrm{ng}$ / $\mathrm{mL}$ ), the mean incorporation/binding of this element into selenoprotein P, GSH-Px and albumin was 57, 20 and 23\%, respectively. Read et al. (1990) showed exactly the same value for selenoprotein $\mathrm{P}$ : about $60 \%$ of Se present in plasma is incorporated into this protein.

Dworkin et al. (1987) found a positive, significant correlation between whole blood Se concentration and serum albumin level in dialyzed patients.
The correlation was even stronger when HD plus CAPD patients and healthy subjects were combined $(\mathrm{r}=0.61, P<0.001)$. Similar results have been presented recently by Zachara et al. (2004b), who demonstrated significant correlations between plasma total protein and Se concentration $(r=0.299)$ as well as between albumin and Se levels $(r=0.326)$ in nondialyzed CKD patients. In another study the same group of researchers (Zachara et al., 2004a) showed a positive correlation between plasma total protein and plasma Se concentration as well as between plasma albumin and Se levels in HD patients. After combining the values of HD patients and controls, these correlations reached a higher level of significance $(\mathrm{r}=0.406$, and $\mathrm{r}=0.456$, respectively; $P<$ 0.0001 in both cases).

Several mechanisms have been reported to explain the altered Se status in uremic patients. The supposed mechanisms comprise (Bonomini \& Albertazzi, 1995): decreased dietary intake, increased urinary or dialytic losses, impaired intestinal absorption, abnormal binding to Se transport proteins or drug therapy. It seems very likely that the main reason for the decreased Se concentration in CKD patients is low protein intake and increased protein loss with urine (Lockitch, 1989; Allan et al., 1999). CKD patients are frequently advised to limit protein consumption (Zachara et al., 2004b). Since protein foodstuffs contain the largest amount of Se (Bonomini \& Albertazzi, 1995; Olson \& Palmer, 1999), reduced protein intake has been suggested as a substantial cause of Se deficiency (Bonomini \& Albertazzi, 1995).

\section{RED CELL AND PLASMA GLUTATHIONE PEROXIDASES}

In general, trace elements function as prosthetic groups of enzymes and Se is an essential component of at least 25 selenoproteins, which have been partially or fully characterized (Burk et al., 2003; Kryukov et al., 2003; Kohrle, 2004; Wastney et al., 2006). Among the five distinct GSH-Pxs identified so far in mammals (Behne \& Kyriakopoulos, 2001), each contains Se in the form of one SeCys residue per subunit or molecule (Arthur, 2000; Behne \& Kyriakopoulos, 2001). Two forms have been identified in blood: cellular (also called cytosolic or classical, GSH-Px 1) present in red blood cells, and extracellular (GSH-Px 3) present in plasma (Arthur \& Beckett, 1994). The activity of cellular GSH-Px was first described by Mills in 1957 and the enzyme was shown to protect red blood cells against hemoglobin oxidation and hemolysis (Mills, 1957). In 1973, Rotruck et al. (1973) in the United States and Flohe et al. (1973) in Germany independently found that 
Se is an integral structural component of the active site of red blood cell GSH-Px. GSH-Px 1 is the most extensively characterized selenoprotein, being found in erythrocytes and cytosol of nearly all tissues of mammals, birds and several other organisms (Zachara, 1992; Behne \& Kyriakopoulos, 2001). It is a tetrameric protein with four identical subunits of 19$24.8 \mathrm{kDa}$ each, depending on the species and tissues examined, with one gram atom of Se in the form of SeCys per subunit (Zachara, 1992). Selenium supplementation has been shown to increase the tissue and red cell protein content of GSH-Px and enzyme activity in HL-60 cells, laboratory animals, livestock and humans (Takahashi et al., 1986). The effect of dietary Se intake on GSH-Px in erythrocytes is apparent and lasts about 100-120 days, which corresponds closely with the life span of these cells and suggests that Se is incorporated into the enzyme only during erythropoiesis.

Another enzyme present in blood is plasma GSH-Px that shows a significant diagnostic value in kidney diseases. Investigating Se deficiency in humans, Cohen et al. (1985) found that after Se supplementation of Se-deficient individuals, plasma GSHPx activity returned to normal values within 4-5 weeks, whereas 3-4 months were required for the red blood cell enzyme to reach this effect. Takahashi and Cohen (1986) have shown that rabbit polyclonal antibodies prepared against purified human red cell GSH-Px precipitate all of the human red cell GSHPx while plasma GSH-Px is not precipitated. This observation suggests that plasma GSH-Px is distinct from the red cell enzyme. Further studies of purified plasma GSH-Px (Takahashi et al., 1987; Zachara, 1992) have shown that this enzyme is structurally, enzymatically and antigenically different from that in erythrocytes and other cells. Plasma GSH-Px, like the red cell enzyme, has a tetrameric form with identical subunits of about $21.5-23.0 \mathrm{kDa}$, with four gram atoms of Se (as SeCys) per mole of the enzyme (Takahashi et al., 1987; Zachara, 1992). As expected for plasma proteins, GSH-Px 3 is a glycoprotein (Takahashi et al., 1987). It has been shown that in humans, plasma GSH-Px is synthesized primarily in the proximal tubular cells of the kidney (Avissar et al., 1994). Along with the kidney, this enzyme is also synthesized in the liver, lung, heart, breast, intestine, brain, skeletal muscle and placenta, from which it is secreted into the extracellular fluid (Chu et al., 1992; Avissar et al., 1994; Behne \& Kyriakopoulos, 2001).

\section{Glutathione peroxidases in blood of patients with chronic kidney disease}

Decreased Se concentrations and GSH-Px activities in blood components are common symptoms in CKD patients, especially in the end-stage renal disease (Trafikowska \& Zachara, 1998). Results of studies on the activity of red blood cell GSH-Px in CKD patients are inconsistent. Numerous authors report significantly lower (Richard et al., 1991; Roxborough et al., 1999; Zachara et al., 2000a; 2001c) or significantly higher activity (Ceballos-Picot et al., 1996), whereas others show similar activities, lower or higher, but not significantly different from those observed in healthy controls (Yoshimura et al., 1996; De Vega et al., 2002; Sommerburg et al., 2002; Zachara et al., 2004a; Stachowska et al., 2005). Zwolinska et al. (2004) have recently revealed that red cell GSHPx activity is significantly lower in children with CKD than in age-matched healthy children, but it is the same in moderate and advanced stages of the disease. On the other hand, Sommerburg et al. (2002) found that red cell GSH-Px activity in children with end-stage CKD was almost twice as high as in agematched controls (23.3 vs. $13.8 \mathrm{U} \mathrm{g} / \mathrm{Hb})$. In contrast, in adult end-stage CKD patients the activity of this enzyme was significantly lower than in children and the same as in healthy subjects (14.0 vs $15.1 \mathrm{U} / \mathrm{g} \mathrm{Hb})$. The authors think that the higher activity of GSH-Px in CKD children may possibly reflect the presence of an adaptation mechanism by which their antioxidant system is enhanced and adapted to the conditions of oxidative stress. Several authors (CeballosPicot et al., 1996; Zachara et al., 2004a; 2004b) have shown that, like in children (Zwolinska et al., 2004), red cell GSH-Px activity in adult CKD patients did not differ significantly between various stages of the disease, regardless of whether it is lower (Zachara et al., 2004b), higher (Ceballos-Picot et al., 1996) or the same (Zachara et al., 2004a) as compared with controls. This means that the synthesis of this enzyme during erythropoiesis in uremic patients is not impaired. The red blood cell GSH-Px activity in various stages of CKD is presented in Fig. 3 (Zachara et al., 2004b).

The red blood cell GSH-Px activity depends on blood Se concentration (Richard et al., 1991), and increases in Se-supplemented CKD patients (SaintGeorges et al., 1989; Richard et al., 1993; Hussein et al., 1997; Koenig et al., 1997). Like in healthy subjects (Zachara, 1992; Iwanier \& Zachara, 1995), the activity of this enzyme increases progressively in CKD patients and reaches a plateau after about 13 weeks (Richard et al., 1991; 1993). Richard et al. (1991) found a high and significant correlation $(r=$ $0.66 ; P<0.005)$ between plasma Se concentration and red cell GSH-Px activity in HD patients. In contrast, Yoshimura et al. (1996) did not find any correlation between these two parameters. Since the low Se level in CKD patients is associated with an increased incidence of malignancy (Lindner et al., 1981; Kallistratos et al., 1985; Vamvakas et al., 1998) and cardiovascular diseases (Amann \& Tyralla, 2002; 

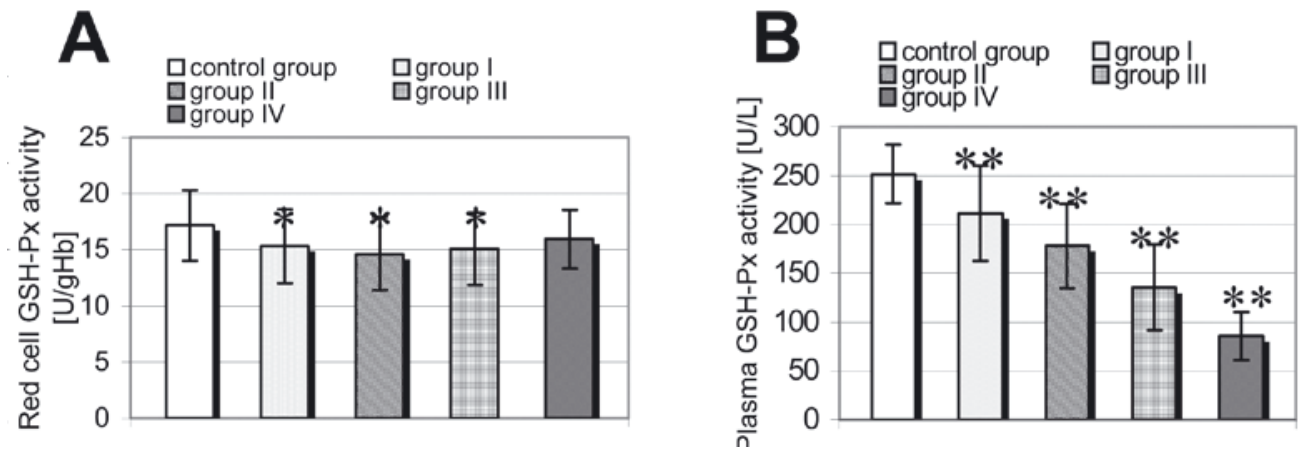

Figure 3. Glutathione peroxidase (GSH-Px) activity in red blood cells (A) and plasma (B) in control group and in patients with chronic kidney disease (CKD) in various stages of the disease.

Patients were divided according to plasma creatinine $(\mathrm{cr}$.) level: group I, incipient $(\mathrm{n}=55)$ with $\mathrm{cr}$. up to $1.36 \mathrm{mg} / \mathrm{dL}$; group II, moderate $(\mathrm{n}=40)$ with mean $\mathrm{cr}$. level $1.72 \mathrm{mg} / \mathrm{dL}$; group III, advanced $(\mathrm{n}=40)$ with mean $\mathrm{cr}$. level $3.96 \mathrm{mg} / \mathrm{dL}$; group IV, end stage $(\mathrm{n}=15)$ with mean cr. level $4.87 \mathrm{mg} / \mathrm{dL}$. Statistics: $*, P<0.01$ vs. control; ${ }^{* *}, P<0.0001$ vs. control (taken from Zachara et al., 2004b).

Go et al., 2004), Se supplementation may prove to be beneficial in preventing these diseases (Bonomini \& Albertazzi, 1995).

In CKD patients, plasma GSH-Px synthesis and activity seem to be much more important than the red cell enzyme. Therefore, we would like to concentrate our attention primarily on the extracellular GSH-Px. Studies on this enzyme have shown that although GSH-Px 3 is synthesized in different tissues (Chu et al., 1992), renal proximal tubular epithelial cells are the main source of the enzyme in plasma (Avissar et al., 1994; Whitin et al., 1998).

It has been shown that kidney has a high concentration of GSH, therefore plasma GSH-Px may have a specific antioxidant function in renal tubules and/or in extracellular spaces (Brown \& Arthur, 2001). GSH, a substrate of GSH-Px, is the most abundant antioxidant inside the cell, where it occurs in a relatively high concentration (Stanczyk et al., 2005). It is the main intracellular defense mechanism against oxidative stress damage, and being a free-radical scavenger, it is directly involved in the reduction of superoxide anion (Vanella et al., 1983). It performs a variety of physiological and metabolic functions, including detoxification reactions against free radicals and toxic compounds (Meister, 1984; Ceballos-Picot et al., 1996). GSH levels in blood of CKD patients vary in different studies. Some authors found the levels unchanged (Mimic-Oka et al., 1991; Canestrari et al., 1994; Pasaoglu et al., 1996), others lower (Vanella et al., 1983; Ceballos-Picot et al., 1996; De Vega et al., 2002) or higher (Cristol et al., 1998; Zachara et al., 2001a) than in healthy controls. Ceballos-Picot et al. (1996) showed that this tripeptide decreased along with the progress of the disease, which in their opinion could be attributed to a reduced synthesis and/or increased degradation. The authors reporting higher levels of GSH in CKD patients indicated that the elevated concentration was maintained during all stages of the disease, which in turn could be recognized as a cell protective mechanism by which the decreased activity of plasma GSH-Px is compensated and thus involved in scavenging of free radicals (Zachara et al., 2001a).

In contrast to the differences in red cell GSHPx activity in CKD patients, found in reports of various authors, plasma GSH-Px activity has always been shown to be reduced by $34-52 \%$ as compared with healthy subjects (Richard et al., 1991; Schiavon et al., 1994; Ceballos-Picot et al., 1996; Yoshimura et al., 1996; Cristol et al., 1998; Zachara et al., 2004b; Zwolinska et al., 2004). Several authors have indicated a gradual decrease in the activity with advancing stage of the disease (Ceballos-Picot et al., 1996; Yoshimura et al., 1996; Zachara et al., 2004b). An example is shown in Fig. 3 (Zachara et al., 2004b). The presence of a negative, statistically significant correlation between plasma GSH-Px activity, creatinine clearance and creatinine concentration (Ceballos-Picot et al., 1996; Yoshimura et al., 1996; Zachara et al., 2004b) as well as between plasma GSH-Px activity and urea nitrogen concentration in plasma (Zachara et al., 2004b) was revealed. In the end-stage CKD, the activity of this enzyme decreased to $34 \%$ of the value observed in the control group. A progressive decline in plasma GSH-Px activity is linked with the fact that this enzyme is primarily synthesized in the kidney (Avissar et al., 1994; Whitin et al., 1998) and - as generally believed - the progressing damage of this organ is reflected in diminished enzyme activity.

Ceballos-Picot et al. (1996) have shown that in HD patients, plasma GSH-Px activity is significantly lower than in non-dialyzed patients with severe CKD and almost completely abrogated $(8.9 \mathrm{U} / \mathrm{mL})$ as compared with controls (71.0 U/mL). Martin-Mateo et al. $(1998 ; 1999)$ demonstrated that in CKD patients, plasma GSH-Px activity was lower by about 50\% than in healthy persons. In their opinion this decline might be associated with a lower enzyme pro- 
duction in the kidney. They also showed (MartineMateo et al., 1999) that after HD session, the enzyme activity increased by $20 \%$ as compared with the preHD value. Roxborough et al. (1999) found that after HD plasma GSH-Px activity increased and reached the value observed in the control group. Both teams (Martin-Mateo et al., 1999; Roxborough et al., 1999) thought that the decreased activity might be attributed, at least in part, to the inhibition caused by ligands or toxic agents of endogenous nature. These inhibitors are most likely removed by dialysis.

As already mentioned, supplementation of healthy persons with selenium leads to an increase in GSH-Px activity in red cells, plasma and other body fluids (Iwanier \& Zachara, 1995; Trafikowska et al., 1998). The results of studies of the effect of Se supply on plasma GSH-Px activity in CKD patients, reported by various authors, are inconsistent. Although a significant increase in plasma Se concentration in this group of patients has been observed (Richard et al., 1993; Zachara et al., 2000a; 2004a), some authors have indicated statistically significant increase in this enzyme's activity (Saint-Georges et al., 1989; Bellisola et al., 1993; Richard et al., 1993), whereas others have noticed no substantial differences (Zachara et al., 2000a). Richard et al. (1993) and Saint-Georges et al. (1989) have shown that plasma GSH-Px activity rose significantly after Se supplementation and reached a plateau after 3-4 months, but it was still lower than in healthy subjects. These discrepancies seem to be associated with the degree of kidney damage in individual study groups of patients. If the patients under study were in the incipient stage of CKD, Se supply induced synthesis of this enzyme in the kidney, which was demonstrated by an increase in its activity. In more advanced stages of the disease, the body response to Se supply, due to a greater kidney damage, was much weaker or totally absent. Some authors (Zachara et al., 2004a) observed that in CKD patients supplemented with $200 \mu \mathrm{g}$ Se/day for 3 months plasma GSH-Px activity increased significantly in the whole group, but particularly in patients in the incipient stage of the disease (creatinine level up to $2.5 \mathrm{mg} / \mathrm{dL}$ ), and did not change significantly compared with its pretreatment values in the advanced stage of the disease (creatinine level $>4.5 \mathrm{mg} / \mathrm{dL}$ (Fig. 4).

A full agreement on whether a decreased plasma GSH-Px activity or a decreased synthesis of this enzyme occurs in CKD patients has not been reached yet. Ceballos-Picot et al. (1996) think that the progressive decline in plasma GSH-Px activity results from a gradual damage of an active part of nephron responsible for the biosynthesis of this enzyme. To clarify the existing doubts whether a decreased activity or a decreased biosynthesis of this peroxidase does occur, Yoshimura et al. (1996) simultaneously determined the activity and concentration of plasma GSH-Px protein in several nondialyzed patients. In the study group, the enzyme activity was by over $50 \%$ lower than in the control group, whereas the protein concentration, measured using anibodies against plasma GSH-Px, was almost below the level of sensitivity or its detection was not possible. The authors conclude that the diminished activity of this enzyme in plasma of the patients was associated with low concentration of the plasma GSH-Px protein. However, it should be noted here that in humans a small amount of plasma GSH-Px is synthesized not only in the kidney (Avissar et al., 1994), but also in several other organs (Chu et al., 1992). The results of the study reported by Yoshimura et al. (1996) show that the decreased concentration of plasma protein GSH-Px may be associated with an impaired biosynthesis of this enzyme in the kidney. In other words, the damaged kidney is able to synthesize only a small amount of the protein, or its synthesizing ability is completely lost. The possibility of an enhanced catabolism of GSH-Px in CKD patients cannot be ruled out. The authors made some other important observations. As it had been previously thought that the diminished activity of

\begin{tabular}{|c|c|}
\hline$\square \mathrm{Tc}$ & $\square$ Cr. up to $25.0 \mathrm{mg} / \mathrm{L} \square \mathrm{Cr} .25 .1-45.0 \mathrm{mg} / \mathrm{L}$ \\
\hline Cr. $>45.0 \mathrm{mg} / \mathrm{L}$ & \\
\hline
\end{tabular}

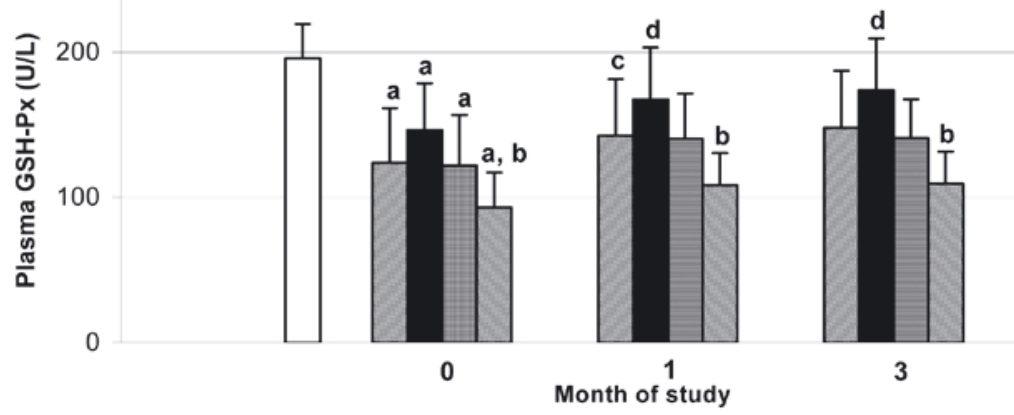

Statistics: $a, p<0.0001$ vs controls; $b, p<0.0001$ vs incipient stage; $c, p<0.01$ vs initial values; $d, p<0.02$ vs initial values
Figure 4. Plasma glutathione peroxidase (GSH-Px) activity in control group and in patients at different stages of chronic kidney disease (CKD) patients supplemented with $200 \mu \mathrm{g}$ Se/day for 3 months.

Taken from Zachara et al., 2004a. 
plasma GSH-Px in CKD patients could be linked with Se deficiency (Richard et al., 1991), Yoshimura et al. (1996) determined plasma Se concentration and GSH-Px activity in red cells. They found in their patients normal Se concentration and higher GSHPx activity in red cells compared with the control group. Another group of researchers (Ceballos-Picot et al., 1996) showed that in CKD patients, plasma Se concentration gradually and significantly decreased with advancing stage of renal failure, while GSH-Px activity in red cells was significantly higher than in controls and was maintained at the same level in all stages of the disease as well as in HD patients. Therefore, the authors (Ceballos-Picot et al., 1996; Yoshimura et al., 1996) conclude that the diminished plasma GSH-Px activity is not linked with Se deficiency in blood. A similar opinion was expressed by other authors (Zachara et al., 2000a; 2004b) on the basis of their own studies.

As to the concentration of the plasma GSHPx protein, Roxborough et al. (1999) presented the results completely opposite to those reported by Yoshimura et al. (1996). They obtained specific antibodies to human plasma GSH-Px, and determined, by applying the ELISA test, the GSH-Px protein in plasma of controls and patients on hemodialysis. They made two observations. First, the activity of this enzyme in pre-HD patients was over $50 \%$ lower than in healthy controls and it significantly increased in post-HD patients, but did not reach the values recorded in the control group. Second, plasma concentration of GSH-Px protein was the same before and after hemodialysis and - which is extremely important - its values did not differ from those observed in healthy controls. The problem of plasma GSH-Px synthesis in CKD patients has not been unequivocally elucidated yet.

Bearing in mind that plasma GSH-Px activity is diminished in all CKD patients, in our opinion the determination of GSH-Px 3 activity in these patients may have certain diagnostic value, which means that this enzyme can be recognized as an additional marker useful in assessing the degree of CKD advancement; the lower the enzyme activity the more advanced the disease stage.

\section{Glutathione peroxidases in blood of patients after kidney transplantation}

Kidney transplantation is now the only treatment that may restore plasma GSH-Px in patients afflicted with end-stage CKD. The data on Se concentration and GSH-Px activities in blood of patients after kidney transplantation are still rather scarce. To the best of our knowledge, there are three different groups of researchers reporting the results on the antioxidant status (mainly plasma GSH-Px) in patients in early stages after kidney transplantation: one in the United States (Avissar et al., 1994; Whitin et al., 1998), one in Spain (De Vega et al., 2002; 2003) and one in Poland (Zachara et al., 2004c; 2005; Wlodarczyk et al., 2005). In the early 1990s, Avissar et al. (1994), searching for the source of plasma GSH$P x$, studied the activity of this enzyme in serum and plasma of seven anephric patients. They found that the activity was $22.6 \%$ of that noted in the four matched controls and was also significantly lower than plasma GSH-Px activity in HD patients. In addition, the authors examined GSH-Px activity and Se concentration in plasma of $96 \mathrm{HD}$ patients and in 11 controls. Patients plasma Se levels were within the normal range, while GSH-Px activity of the HD patients was $42 \%$ of the activity of the control group $(P<0.001)$. The authors proved that the reduction in plasma GSH-Px activity could not be attributed to the lowered Se concentrations because: 1) the Se level in the patients' plasma was not significantly different from that in controls $(118$ vs. $130 \mathrm{ng} / \mathrm{mL}$, respectively); 2) when the patients were divided into two subgroups by Se levels (11 persons with the level < $96 \mathrm{ng} / \mathrm{mL}$, and 12 with the level $>138 \mathrm{ng} / \mathrm{mL}$ ), there was no significant difference in their plasma GSH-Px activity (0.129 and $0.159 \mathrm{U} / \mathrm{mL}$, respectively); and 3) the patients showed high $(142 \%$ of the control value) red blood cell GSH-Px activity. In sera of three transplanted patients, Se levels and GSH-Px activities were measured 22 and 30 days after surgery. Se level was the same as prior to transplantation, while the plasma GSH-Px activity was eight times higher than before surgery and two times higher than in controls. Several months after transplantation, the plasma GSH-Px activity returned to normal values of healthy persons. These results suggest that the kidney supplies a major portion of plasma GSH-Px activity. The authors have also shown the absence of an inhibitory effect of anephric plasma on GSH-Px activity in the control plasma: there was no inhibition of GSH-Px activity of normal plasma on addition of plasma from anephric patients. Thus the authors: 1) rule out the inhibitory effect of plasma metabolites or uremic toxins on the enzyme activity; and 2) indicate that the lowered Se level is not a limiting factor for GSH-Px synthesis. These two facts are very often suggested by some authors to be the cause of the lowered plasma GSH-Px activity in CKD patients.

Four years after the previous transplantation, Whitin et al. (1998), from the same center, transplanted kidneys in three groups of patients: 1) sixteen adults with renal disease who received a kidney transplant from related donors; 2) six adult patients who received cadaveric kidney transplants; and 3) three pediatric patients undergoing bilateral nephrectomy with subsequent kidney transplanta- 
tion from related donors. Before transplantation, the HD patients had the plasma GSH-Px activity of $34 \%$ (group 1) and $50 \%$ (group 2) of the control plasma, while the anephric individuals (group 3) had the plasma GSH-Px activity ranging from 2 to $24 \%$ of that recorded in controls. After transplantation, the plasma GSH-Px activity increased very rapidly: in group 1, the enzyme activity was two times higher three days after transplantation than before operation, and 21 days post-transplant the averaged activities were within the normal values. In group 2, the plasma GSH-Px activity increased rapidly over the first two weeks post kidney transplant. In six patients of this group, plasma GSH-Px activity reached the normal level after 9.8 days, and 27 days post-transplant the plasma enzyme activity reached a maximum level $-144 \%$ of the control value. The maximum level was temporary and after several weeks it decreased to a range similar to that of healthy individuals. In two patients of group 3, plasma GSH-Px activity increased rapidly within two weeks following kidney transplantation, while in the third patient this period was quite longer. The data presented by the authors show that in patients undergoing kidney transplantation, plasma GSH-Px activity increases rapidly - within 2 weeks posttransplant.

Quite recently Zachara et al. (2004c) have shown that in 30 patients before kidney transplantation the Se concentration in whole blood and plasma was lower by about $20 \%$ as compared with controls $(P<0.0001)$ and within a week after operation it significantly decreased. The reason for the decrement just after operation was not known but could probably be linked with the restricted diet of the operated patients and thus with the extremely low Se intake. During the first $36-48 \mathrm{~h}$ after surgery, the patients received only intravenous and oral fluids containing no protein - the main source of Se. From the second day, a diet, containing progressively up to $70 \mathrm{~g}$ of protein, was being introduced, so that the Se level increased slowly, but even 3 months following transplantation it was still significantly lower than in healthy subjects.

Zachara et al. (2004c; 2005) have shown that before transplantation as well as within a 3-month period after surgery the red cell GSH-Px activity in the patients was the same as in healthy controls. However, plasma GSH-Px activity before transplantation $(75.6 \mathrm{U} / \mathrm{L})$ was by $69 \%$ lower in patients than in the control group $(243 \mathrm{U} / \mathrm{L}, P<0.0001)$, after 3 days it increased rapidly to $115 \mathrm{U} / \mathrm{L}$, and 2 weeks after surgery it doubled $(164 \mathrm{U} / \mathrm{L})$ the initial value $(P<$ 0.0001). Unlike to other authors (Avissar et al., 1994, Whitin et al., 1998), 3 months after transplantation the activity was still significantly lower than that of the control group (Zachara et al., 2004c). The authors also showed that in transplanted patients who were not dialyzed after surgery $(n=7)$, or were dialyzed only once just after surgery $(n=4)$ (subgroup 1$)$, the plasma GSH-Px activity, throughout a 3-month period, was significantly higher $(0.001<P<0.05)$ than in patients who had 2-11 HD sessions $(\mathrm{n}=19)$ (subgroup 2). On the contrary, between day 3 and day 30 after transplantation, creatinine concentration was significantly lower in subgroup $1(0.0001<P<0.01)$ than in subgroup 2. Although there is as yet no conclusive explanation for the disparate results of this observation, the authors speculate that immediate or delayed assumption of function of the transplanted kidney could be the main causative factor (Zachara et al., 2004c). Therefore, monitoring of plasma GSHPx activity may be an additional useful marker for the transplanted kidney function.

Selenium supplementation to kidney transplant recipients has a positive effect on the antioxidant system. Hussein et al. (1997) have shown that treatment of allograft recipients with $200 \mu \mathrm{g}$ Se/day results in a reduction in drug-induced plasma lipid peroxidation, a significant elevation of GSH content as well as of red cell GSH-Px and glutathione reductase activities. Wlodarczyk et al. (2005) have

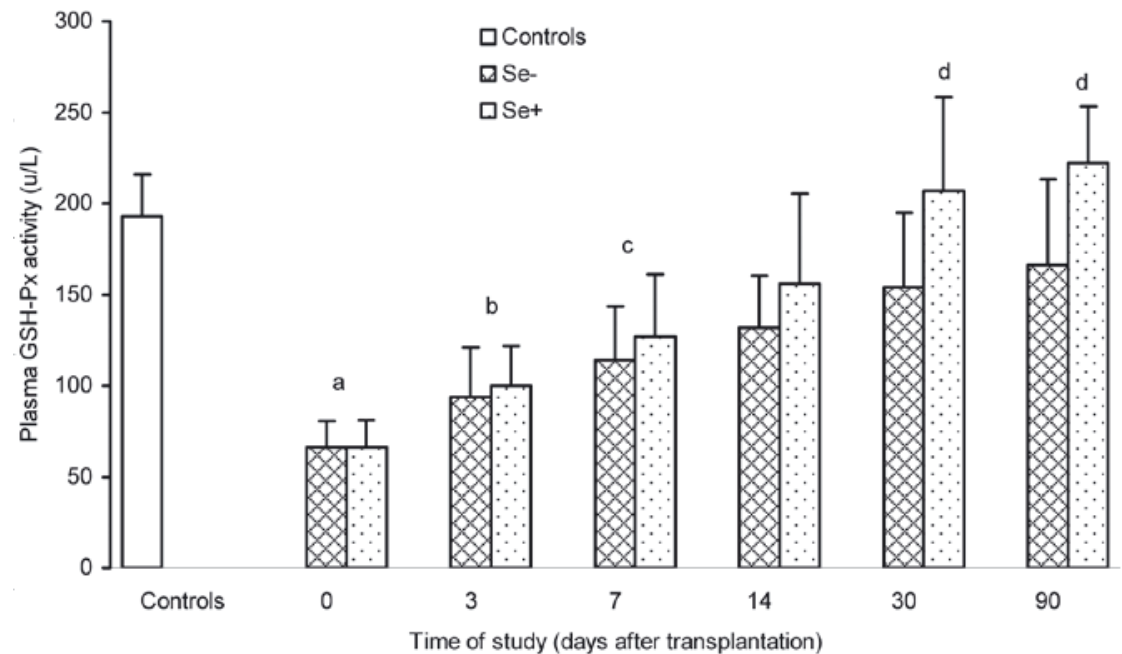

Time of study (days after transplantation)
Figure 5. Plasma glutathione peroxidase activity in control group and in patients before and after kidney transplantation supplemented and nonsupplemented with Se.

Statistics: a, $P<0.0001$ vs. control group; $\mathrm{b}, P<0.01$ vs. initial values (in both groups taken separately); c, $P<0.0001$ vs. initial values (in both groups taken separately); $\mathrm{d}, P$ $<0.01$ vs. supplemented and non-supplemented patients (taken from Wlodarczyk et al., 2005). 
confirmed these results, indicating that kidney transplantation restores very rapidly plasma GSH-Px activity and have also shown that Se supplementation in a dose of $200 \mu \mathrm{g} /$ day to patients after kidney transplantation induces more evident synthesis of this enzyme (Fig. 5). In comparison with the placebo group, the activity of plasma GSH-Px in Sereceiving patients was slightly higher 3 to 14 days after surgery and significantly higher $(P<0.001) 1-3$ months post transplantation. Three months after surgery, plasma GSH-Px activity in the placebo group reached almost the value of control subjects while in the Se-supplemented patients it was significantly higher $(P<0.0001)$ as compared with controls. These results (Wlodarczyk et al., 2005) again show that after transplantation, the kidney normalizes its function very rapidly and synthesizes GSH-Px. Furthermore, the transplanted kidney responds positively to the induction of Se supply and - contrary to patients in end stage of CKD - synthesizes GSH-Px.

Contrary to the results presented by some of the aforesaid authors (Avissar et al., 1994; Whitin et al., 1998; Zachara et al., 2004c; Wlodarczyk et al., 2005), De Vega et al. (2002; 2003) found quite different results of plasma GSH-Px activity in patients in early stages after kidney transplantation. They namely showed that $48 \mathrm{~h}$ following kidney transplantation the plasma GSH-Px activity decreased by $11 \%$ as compared with the pre-transplant value, whereas 7 and 14 days after surgery the enzyme activity increased by only 11 and $17 \%$ as compared to the initial value $(P>0.05)$. The differences in plasma GSH-Px activities within 2-30 days after kidney transplantation, presented by various authors, are shown in Fig. 6 (Zachara et al., 2005). The reason for the decreased GSH-Px activity $48 \mathrm{~h}$ after transplantation and the lack of significant differences within the two-week period following surgery presented by the authors (De Vega et al., 2002; 2003) remains merely a speculation. The authors suggest that it may be due to the blockade by malonyldialdehyde (MDA - the end product of lipid peroxidation and an indirect index of oxidative injury) or other toxic compounds generated by the attack of free radicals or by a decreased level of Se. Both suggestions seem to be unlikely since in their study the level of MDA before transplantation and $48 \mathrm{~h}$ after surgery did not differ from that in the control group (Fernandez et al., 2002), and a lowered Se concentration, as shown by other authors (Avissar et al., 1994; Ceballos-Picot et al., 1996; Yoshimura et al., 1996; Zachara et al., 2000a; 2004b), has no influence on plasma GSH-Px activity in uremic patients. The authors (De Vega et al., 2002; 2003) did not measure Se concentration in blood or plasma. Further studies are required to elucidate the discrepancies.

Several authors have published results of long-term studies of Se concentration and plasma GSH-Px activity in patients after kidney transplantation. Some of them (Wlodarczyk et al., 2003; Morris-Stiff et al., 2004) show that plasma Se concentration in kidney transplanted recipients normalizes in the majority of patients by 3-6 months after surgery. Morris-Stiff et al. (2004) presented data on plasma Se concentration in 40 patients undergoing cadaveric kidney transplantation. At the time of transplantation, low plasma Se concentration was found in 30 patients. Twenty patients received cyclosporine A (Cs A) and 20 tacrolimus. Three months after surgery, of the 40 patients 28 had plasma Se concentration within the range of healthy subjects. Three, six, and twelve months after surgery, mean plasma Se concentration exceeded the baseline values in both groups of patients. Se concentrations were significantly lower at the 3rd month in patients who experienced clinical acute rejection (CAR) or cytomegalovirus (CMV) infection. Nevertheless, after 12 months the concentrations were normalized and were the same in patients with or without symptoms of CAR and CMV infection. Wlodarczyk et al. (2003) have shown that, starting from the 7th day after kidney transplantation, mean whole blood and plasma Se concentrations increased gradually and at 6th month reached the value of the control group. Turan et al.

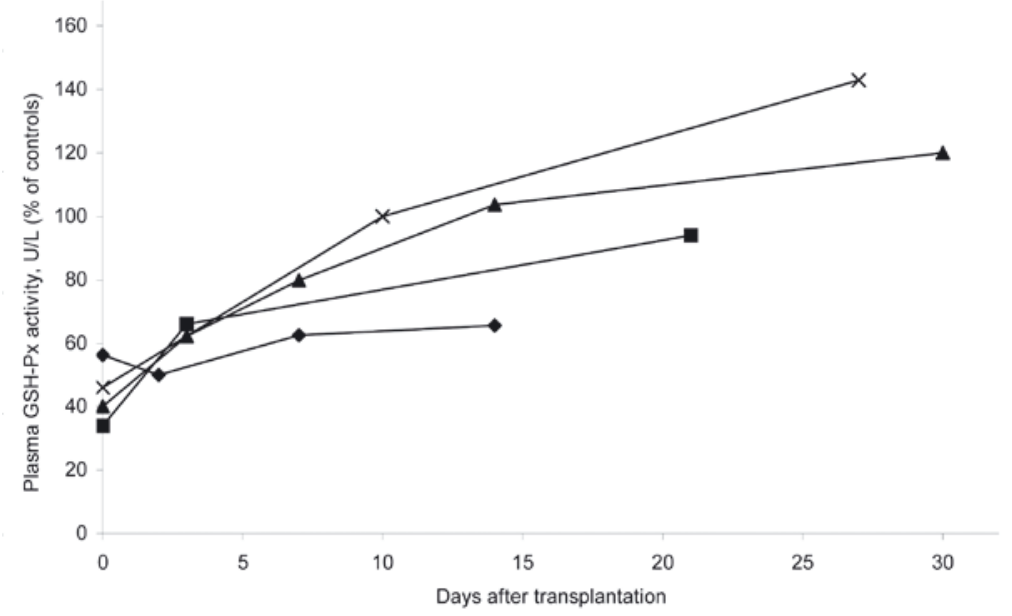

Figure 6. Plasma GSH-Px activity in pre- and post-kidney-transplant patients presented by different authors.

Means \pm S.D. for plasma glutathione peroxidase (GSH-Px) activity as the percentage of control plasma GSH-Px activity are given: our study $(\mathbf{\Delta})$ (Zachara et al., 2005), and studies carried out by Within et al. (1998): recipients with cadaveric kidney (ם); patients receiving kidney from related donors $(\mathbf{x})$; and study carried out by De Vega et al. (2002) (taken from Zachara et al., 2005). 
(1992) found that in 30 transplanted patients, 5-53 months (mean, 19.9) after surgery, the mean plasma Se concentration was higher by $35 \%(P<0.0001)$ as compared with controls.

Wlodarczyk et al. (2003) found no changes in red cell GSH-Px activity in kidney transplanted patients just after surgery and within a 6-month period following operation; the values were the same as in controls. Juskowa et al. (2000) have shown that in patients who, after kidney transplantation, were treated for 4 years with triple-drug therapy (prednisone, azathioprine and cyclosporine A), red cell GSH-Px activity was significantly lower $(P<0.02)$, while in patients treated with two drugs only (without cyclosporine A), the activity after 10.8 years was the same as in controls. Cyclosporine A is known as a nephrotoxic drug, induces the production of ROS (Kasiske, 2002). In contrast, Simic-Ogrizovic et al. (1998) have shown that in patients treated with triple-drug therapy (the same as in Juskowa et al., 2000), 5 years after kidney transplantation, the red cell GSH-Px activity in transplant recipients with stable kidney function was higher by $28 \%$, whereas in a group of patients with chronic rejection it was higher by $63 \%$ as compared with controls.

There are contradictory data on plasma GSHPx activity in kidney recipients several months to several years after transplantation. Some authors found significantly lower plasma GSH-Px activity 5 years after operation (Turan et al., 1992), and - since they found high cadmium concentration in sera - they thought that this metal with a high affinity for the $-\mathrm{SH}$ groups of the enzyme might inactivate GSH-Px. Kim et al. (2000) showed that 32.4 months after kidney transplantation plasma GSH-Px activity was the same as in the control group although the MDA level was significantly higher in transplant recipients. Similar results were presented by other authors (Simic-Ogrizovic et al., 1998): in patients with stable kidney function, 5 years following kidney transplantation, although the MDA level in plasma was 4 times higher than in controls, plasma GSH-Px activity did not differ between those two groups. On the other hand, in kidney recipients with histologically proven chronic rejection, the MDA level was 3 times higher than in controls, while plasma GSH-Px activity was lower $(24.7 \%$; $P<0.05)$ than in healthy subjects. The authors (Kim et al., 2000) thus think that the significantly lower plasma GSH-Px activity in patients with chronic rejection symptoms was most probably a consequence of impaired production of GSH-Px in the transplanted kidney. This opinion contradicts the data of Cristol et al. (1992; 1996) who showed that in kidney recipient patients, both in stable function and chronic rejection, the level of plasma GSH-Px protein was significantly higher (by $109-112 \%$ and $32-61 \%$, respectively) than in healthy volunteers. The significant increase in plasma GSH-Px protein level could result from an induction of GSH-Px synthesis. The patients with stable function of the transplanted kidney are able to synthesize more enzyme than those with an impaired kidney function.

In conclusion, Se concentration in whole blood and plasma of CKD patients is very often lower than in healthy controls. Several to a dozen months after kidney transplantation, Se concentrations in whole blood and plasma return to normal values. The red blood cell GSH-Px activity in CKD patients is usually unchanged although some authors found lower or higher values. Plasma GSH-Px activity is always reduced and the reduction increases with increasing stage of the disease. In Se-supplemented CKD patients plasma GSH-Px activity rises slightly in the early stages of the disease and remains unchanged in end-stage CKD. After kidney transplantation, plasma GSH-Px activity increases very rapidly and several months - years after surgery it is usually the same as in healthy subjects. Measurement of plasma GSH-Px activity in CKD patients and in transplant recipients may be an additional marker in the diagnosis of the stage of uremia or the function of the transplanted kidney. The data show that the kidney plays an important role in Se homeostasis and is the predominant source of plasma GSH-Px.

\section{Acknowledgements}

This work was supported in part by grant No. PB 0710/P05/2004/27 from the State Committee for Scientific Research (KBN, Warszawa, Poland).

B.A.Z. expresses his gratitude to the Foundation for Polish Science (FNP, "Nestor"), for providing an individual grant.

\section{REFERENCES}

Alaejos MS, Romero CD (1993) Urinary selenium concentrations. Clin Chem 39: 2040-2052.

Allan CB, Lacourciere GM, Stadtman TC (1999) Responsiveness to selenoproteins to dietary selenium. Annu Rev Nutr 19: 1-16.

Amann K, Tyralla K (2002) Cardiovascular changes in chronic renal failure - pathogenesis and therapy. Clin Nephrol 58: S62-S72.

Arthur JR, Beckett GJ (1994) Newer aspects of micronutrients in at risk groups. New metabolic roles for selenium. Proc Nutr Soc 53: 615-624.

Arthur JR (2000) The glutathione peroxidases. Cell Mol Life Sci 57: 1825-1835.

Avissar N, Ornt DB, Yagil Y, Horovitz S, Watkins RH, Kerl EA, Takahashi K, Palmer IS, Cohen HJ (1994) Human kidney proximal tubules are the main source of plasma glutathione peroxidase. Am J Physiol 266 (Cell Physiol 35): C367-C375.

Baynes JW, Thorpe SR (1999) Role of oxidative stress in diabetic complications. Diabetes 48: 1-9. 
Behne D, Kyriakopoulos A (2001) Mammalian seleniumcontaining proteins. Annu Rev Nutr 21: 453-473.

Bellisola G, Perona G, Galassini S, Moschini G, Guidi GC (1993) Plasma selenium and glutathione peroxidase activities in individuals living in the Veneto region of Italy. J Trace Elem Electrolytes Health Dis 7: 242-244.

Bonomini M, Albertazzi A (1995) Selenium in uremia. Artif Organs 19: 443-448.

Bonomini M, Forster S, Manfrini V, De Risio F, Steiner M, Vidovich MI, Klinkmann H, Ivanovich P, Albertazzi A (1996) Geographic factors and plasma selenium in uremia and dialysis. Nephron 72: 197-204.

Brown KM, Arthur JR (2001) Selenium, selenoproteins and human health: a review. Public Health Nutr 4: 595-599.

Burk RF, Hill KE, Motley AK (2003) Selenoprotein metabolism and function: Evidence for more than one function for selenoprotein P. J Nutr 133: 1517S-1520S.

Burk RE, Hill KE (2005) Selenoprotein P: an extracellular protein with unique physical characteristics and role in selenium homeostasis. Annu Rev Nutr 25: 11.1-11.21.

Byard JL (1969) Trimethyl selenide. A urinary metabolite of selenite. Arch Biochem Biophys 130: 556-560.

Canestrari F, Galli F, Giorgini A, Albertini MC, Galatia P, Pascucci M, Bossu M (1994) Erythrocyte redox state in uremic anemia: effects of hemodialysis and relevance of glutathione metabolism. Acta Haematol 91: 187-193.

Castro L, Freeman BA (2001) Reactive oxygen species in human health and disease. Nutrition 17: 161-165.

Ceballos-Picot I, Witko-Sarsat V, Merad-Boudia M, Nguyen AT, Thevenin M, Jaudon MC, Zingraff J, Verger C, Jungers P, Descamps-Latscha B (1996) Glutathione antioxidant system as a marker of oxidative stress in chronic renal failure. Free Rad Biol Med 21: 845-853.

Chu FF, Esworthy S, Doroshow JH, Doan K, Liu XF (1992) Expression of plasma glutathione peroxidase in human liver in addition to kidney, heart, lung, and breast in humans and rodents. Blood 79: 3233-3238.

Cohen HJ, Chovaniec ME, Mistretta D, Baker SS (1985) Selenium repletion and glutathione peroxidase - differential effects on plasma and red blood cell enzyme activity. Am J Clin Nutr 41: 735-747.

Combs GF Jr, Combs SB (1984) The nutritional biochemistry of selenium. Annu Rev Nutr 4: 257-280.

Cristol JP, Maggi MF, Vela C, Descomps B, Mourad G (1996) Lipid metabolism and oxidative stress in renal transplantation: implications for chronic rejection. Transpl Proc 28: 2820-2821.

Cristol J-P, Vela C, Maggi M-F, Descomps B, Mourad G (1998) Oxidative stress and lipid abnormalities in renal transplant recipients with or without chronic rejection. Transplantation 65: 1322-1328.

De Vega L, Fernandez RP, Martin Mateo MC, Bustamante J, Bustamante A, Herrero AM, Bustamante Munguira E (2003) Study of the activity of glutathione-peroxidase, glutathione-transferase, and glutathione-reductase in renal transplants. Transpl Proc 35: 1346-1350.

De Vega L, Fernandez RP, Martin Mateo MC, Bustamante JB, Herrero AM, Munguira EB (2002) Glutathione determination and a study of the activity of glutathioneperoxidase, glutathione-transferase, and glutathione-reductase in renal transplants. Renal Failure 24: 421-432.

Deagan JT, Butler JA, Zachara BA, Whanger PD (1993) Determination of the distribution of selenium between glutathione peroxidase, selenoprotein $\mathrm{P}$, and albumin in plasma. Anal Biochem 208: 176-181.

Dworkin B, Weseley S, Rosenthal WS, Schwartz EM, Weiss L (1987) Diminished blood selenium levels in renal fail- ure patients on dialysis: correlations with nutritional status. Am J Med Sci 30: 6-12.

Fantel AG (1996) Reactive oxygen species in developmental toxicity: Review and hypothesis. Teratology 53: 196-217.

Fernandez RP, Martin-Mateo MC, De Vega L, Bustamante J, Herrero M, Bustamante Munguira E (2002) Antioxidant enzyme determination and a study of lipid peroxidation in renal transplantation. Renal Failure 24: 353-359.

Flohe L, Gunzler WA, Schock HH (1973) Glutathione peroxidase: a selenoenzyme. FEBS Lett 32: 132-134.

Foote JW, Hinks LJ, Lloyd B (1987) Reduced plasma and white blood cell selenium levels in haemodialysis patients. Clin Chim Acta 164: 323-328.

Francesconi K (2006) Urinary excretion of selenium. In 8th Int Symp on Selenium in Biology and Medicine, University of Madison, Madison, WI, USA, July 26-30, 2006, Conference Book p 21.

Francesconi KA, Pannier F (2004) Selenium metabolites in urine: A critical overview of past work and current status. Clin Chem 50: 2240-2253.

Galli F, Canestrari F, Buoncristiani U (1999) Biological effects of oxidant stress in haemodialysis: The possible roles of vitamin E. Blood Purif 17: 79-94.

Girelli D, Olivieri O, Stanzial AM, Azzini M, Lupo A, Bernich P, Menini C, Gammaro L, Corrocher R (1993) Low platelet glutathione peroxidase activity and serum selenium concentration in patients with chronic renal failure: relations to dialysis treatments, diet and cardiovascular complications. Clin Sci 84: 611-617.

Go AS, Chertow GM, Fan D, McCulloch CE, Hsu C-Y (2004) Chronic kidney disease and the risks of death, cardiovascular events, and hospitalization. $N$ Engl J Med 351: 1296-1305.

Grignard E, Morin J, Vernet P, Drevet JR (2005) GPX5 orthologs of the mouse epididymis-restricted and spermbound selenium-independent glutathione peroxidase are not expressed with the same quantitative and spatial characteristics in large domestic animals. Theriogenology 64: 1016-1033.

Halliwell B, Gutteridge JMC (1989) Free Radicals in Biology and Medicine. Oxford University Press, Oxford.

Hussein O, Rosenblat M, Refael G, Aviram M (1997) Dietary selenium increases cellular glutathione peroxidase activity and reduces the enhanced susceptibility to lipid peroxidation of plasma and low-density lipoprotein in kidney transplant recipients. Transplantation 63: 679-685.

Iwanier K, Zachara BA (1995) Selenium supplementation enhances the element concentration in blood and seminal fluid but does not change the spermatozoa quality characteristics in subfertile men. J Androl 16: 441-447.

Jamieson D (1989) Oxygen toxicity and reactive oxygen metabolites in mammals. Free Radic Biol Med 7: 87-108.

Joseph M (1995) The generation of free radicals by blood platelets. In Immunology of Platelets (Joseph M, ed) pp 209-225. Academic Press, London-Toronto.

Juskowa J, Paczek L, Laskowska-Klita T, Gajewska J, Oldakowska-Jedynak U, Szymczak E, Foroncewicz B, Chelchowska M, Mucha K (2000) Antioxidant potential in renal allograft recipients with stable graft function. Transpl Proc 32: 1353-1357.

Kallistratos G, Evangelou A, Seferiadis K, Vezyraki P, Barboutis K (1985) Selenium and haemodialysis: serum selenium levels in healthy persons, non-cancer and 
cancer patients with chronic renal failure. Nephron 41: 217-222.

Kasiske BL (2002) Cyclosporine and lipid peroxidation. Am J Kidney Dis 31: 149-154.

Kim YH, Mun KC, Lee SS, Seo SH, Kwak CS, Park SB, Kim HC (2000) Oxidative damage in renal transplant patients. Transplant Proc 32: 1777-1778.

Kobayashi Y, Ogra Y, Ishiwata K, Takayama H, Aimi N, Suzuki KT (2002) Selenosugars are key and urinary metabolites for selenium excretion within the required to low-toxic range. Proc Natl Acad Sci USA 99: 1593215936.

Koenig JS, Fischer M, Bulant E, Tiran B, Elmadfa I, Druml W (1997) Antioxidant status in patients on chronic hemodialysis therapy: impact of parenteral selenium supplementation. Wien Klin Wochenschr 109: 13-19.

Kohrle J (2004) Selenium in biology and medicine - further progress and increasing interest. J Trace Elem Med Biol 18: 61-63.

Kryukov GV, Castellano S, Novoselov SV, Lobanov AV, Zehtab O, Guigo R, Gladyshev VN (2003) Characterization of mammalian selenoproteomes. Science 300: 1439-1443.

Kuehnelt D, Juresa D, Kienzl N, Francesconi KA (2006) Marked individual variability in the levels of trimethylselenonium ion in human urine determined by HPLC/ ICPMS and HPLC/vapor generation ICPMS. Anal Bioanal Chem 386: 2207-2212.

Kuroda M, Imura T, Morikawa K, Hasegawa T (1988) Decreased serum levels of selenium and glutathione peroxidase activity associated with aging, malignancy and chronic hemodialysis. Trace Elem Med 5: 97-103.

Lachili B, Arnaud J, Coudray C, Zama N, Roussel AM, Benlatreche C, Favier A (1996) Serum trace elements $(\mathrm{Cu}, \mathrm{Zn}, \mathrm{Se}$, and $\mathrm{Al})$ and thiobarbituric acid reactants (TBARS) in hemodialysis patients from Batna (Algeria); In Therapeutic Uses of Trace Elements (Neve J, ed) pp 185-188. Plenum Press, New York.

Lim P-S, Cheng Y-M, Wei Y-H (2002) Increase in oxidative damage to lipids and proteins in skeletal muscle of uremic patients. Free Radic Res 36: 295-301.

Lindner A, Farewell VT, Sherrard DJ (1981) High incidence of neoplasia in uremic patients receiving longterm dialysis. Cancer and long-term dialysis. Nephron 27: 292-296.

Lockitch G (1989) Selenium: Clinical significance and analytical concepts. Crit Rev Clin Lab Sci 27: 483-541.

Loughrey CM, Young IS, Lightbody JH, McMaster D, McNamee PT, Trimble ER (1994) Oxidative stress in haemodialysis. Q J M 87: 679-683.

Marchante-Gayon JM, Sanchez-Uria JE, Sanz-Mede A (1996) Serum and tissue selenium contents related to renal disease and colon cancer as determined by electrothermal atomic absorption spectrometry. J Trace Elem Med Biol 10: 229-236.

Martin-Mateo MC, Del Canto-Jafiez E, Barrero-Martinez MJ (1998) Oxidative stress and enzyme activity in ambulatory renal failure patients undergoing continuous peritoneal dialysis. Renal Failure 20: 117-124.

Martin-Mateo MC, Sanchez-Portugal M, Iglesias S, De Paula A, Bustamante J (1999) Oxidative stress in chronic renal failure. Renal Failure 21: 155-167.

Marx L (1987) Oxygen free radicals linked to many diseases. Science 30: 529-531.

Medina D, Thompson H, Ganther H, Ip C (2001) Se-methylselenocysteine: a new compound for chemoprevention of breast cancer. Nutr Cancer 40: 12-17.

Meier B (2001) Reactive oxygen intermediates involved in cellular regulation. Protoplasma 217: 101-116.
Meister A (1984) New developments in glutathione metabolism and their potential application in therapy. Hepatology 4: 739-742.

Mills GC (1957) Hemoglobin catabolism. I. Glutathione peroxidase, an erythrocyte enzyme which protects hemoglobin from oxidative breakdown. J Biol Chem 229: 189-197.

Milly K, Wit L, Diskin C, Tulley R (1992) Selenium in renal failure patients. Nephron 61: 139-144.

Mimic-Oka J, Djukanovic L, Simic T, Stefanovski J, Ramic Z (1991) Glutathione and its associated enzymes in chronic renal failure. Amino Acids 1: 169-170.

Morris-Stiff GJ, Oleesky DA, Smith SC, Jurewicz WA (2004) Sequential changes in plasma selenium concentration after cadaveric renal transplantation. Br J Surg 91: 339-343.

Neve J (1991) Physiological and nutritional importance of selenium. Experientia 47: 187-193.

Olson OE, Palmer IS (1984) Selenium in foods purchased or produced in South Dakota. Food Sci 49: 446-452.

Palmer IS, Fischer DD, Halverson AW, Olson OE (1969) Identification of a major selenium excretory product in rat urine. Biochim Biophys Acta 177: 336-342.

Palmer IS, Gunsalus RP, Halverson AW, Olson OE (1970) Trimethylselenonium ion as a general excretory product from selenium metabolism in the rat urine. Biochim Biophys Acta 208: 260-266.

Pasaoglu H, Muhtaroglu S, Gunes M, Utas C (1996) The role of the oxidative state of glutathione and glutathione-related enzymes in anemia of hemodialysis patients. Clin Biochem 29: 567-572.

Patching SG, Gardiner PHE (1999) Recent developments in selenium metabolism and chemical speciation: A review. J Trace Elem Med Biol 13: 193-214.

Read R, Bellew T, Yang J-G, Hill KE, Palmer IS, Burk RF (1990) Selenium and amino acid composition of selenoprotein $\mathrm{P}$, the major selenoprotein in rat serum. $J$ Biol Chem 265: 17899-17905.

Richard MJ, Arnaud J, Jurkovitz C, Hachache T, Meftachi H, Laporte F, Foret M, Favier A, Corolonnier D (1991) Trace elements and lipid peroxidation abnormalities in patients with chronic renal failure. Nephron 57: 10-15.

Richard MJ, Ducros V, Foret M, Arnaud J, Coudray C, Fusselier M, Favier A (1993) Reversal of selenium and zinc deficiencies in chronic hemodialysis patients by intravenous sodium selenite and zinc gluconate supplementation. Biol Trace Elem Res 39: 149-159.

Robberecht HJ, Deelstra HA (1984) Selenium in human urine: concentration levels and medical implications. Clin Chim Acta 136: 107-120.

Rotruck JT, Pope AL, Ganther HE, Swanson A, Hafeman DG, Hoekstra WG (1973) Selenium - biological role as a component of glutathione peroxidase. Science 179: 588-590.

Roxborough HE, Mercer C, McMaster D, Young IS (1999) Plasma glutathione peroxidase activity is reduced in haemodialysis patients. Nephron 81: 278-283.

Saint-Georges MD, Bonnefont DJ, Bourely BA, Jaudon MCT, Cereze P, Chaumeil P, Gard C, D'Auzac CL (1989) Correction of selenium deficiency in hemodialyzed patients. Kidney Int 16 (Suppl. 1): S274-S277.

Saito T, Takahashi K (2000) Selenoprotein P: Its structure and functions. J Health Sci 46: 409-413.

Schiavon R, Guidi GC, Biasioli S, De Fanti E, Targa L (1994) Plasma glutathione peroxidase activity as an index of renal function. Eur J Clin Biochem 32: 759-765.

Simic-Ogrizovic S, Simic T, Reljic Z, Markovic S, Blagojevic R, Radivojevic D, Lezaic V, Djukanovic LJ, Mimic-Oka 
J (1998) Markers of oxidative stress after renal transplantation. Transpl Int 11 (Suppl. 1): S125-S129.

Sommerburg O, Grune T, Ehrich JHH, Siems WG (2002) Adaptation of glutathione peroxidase activity to oxidative tress occurs in children but not in adult patients with end-stage renal failure undergoing hemodialysis. Clin Nephrol 58 (Suppl 1): S31-S36.

Stachowska E, Wesolowska T, Olszewska M, Safranow K, Millo B, Domanski L, Jakubowska K, Ciechanowski K, Chlubek D (2005) Elements of Mediterranean diet improves oxidative status in blood of kidney graft recipients. Br J Nutr 93: 345-352.

Stanczyk M, Gromadzinska J, Wasowicz W (2005) Roles of reactive oxygen species and selected antioxidants in regulation of cellular metabolism. Int J Occup Med Environ Health 18: 15-26.

Suzuki KT (2005) Metabolomics of selenium: Se metabolites based on speciation studies. J Health Sci 51: 107114.

Suzuki K (2006) Metabolomics of selenium with multiple stable isotopes. In 8th Int Symp on Selenium in Biology and Medicine; University of Wisconsin, Madison, WI, USA, July 25-30, 2006, Conference Book p 20.

Suzuki KT, Kurasaki K, Okazaki N, Ogra Y (2005) Selenosugar and trimethylselenonium among urinary Se metabolites: dose- and age-related changes. Toxicol Appl Pharmacol 206: 1-8.

Takahashi K, Avissar N, Whitin J, Cohen HJ (1987) Purification and characterization of human plasma glutathione peroxidase: a selenoglycoprotein distinct from the known cellular enzyme. Arch Biochem Biophys 256: 677-686.

Takahashi K, Cohen HJ (1986) Selenium-dependent glutathione peroxidase protein and activity: immunological investigation on cellular and plasma enzymes. Blood 68: 640-645.

Takahashi K, Newburger PE, Cohen HJ (1986) Glutathione peroxidase protein. Absence in selenium deficiency states and correlation with enzymatic activity. J Clin Invest 77: 1402-1404.

Trafikowska U, Sobkowiak E, Butler JA, Whanger PD, Zachara BA (1998) Organic and inorganic selenium supplementation to lactating mothers increase the blood and milk Se concentrations and Se intake by breast-fed infants. J Trace Elem Med Biol 12: 77-85.

Trafikowska U, Zachara BA (1998) Selenium and some antioxidants in blood of patients with chronic renal failure. Pol Merk Lek 5: 178-182 (in Polish).

Tsukamoto Y, Iwamami S, Marumo F (1980) Disturbance of trace element concentrations in plasma of patients with chronic renal failure. Nephron 26: 174-179.

Turan B, Delilbasi E, Dalay N, Sert S, Afrasyap L, Sayal A (1992) Serum selenium and glutathione peroxidase activities and their interaction with toxic metals in dialysis and renal transplantation patients. Biol Trace Elem Res 33: 95-102.

Vamvakas S, Bahner U, Heidland A (1998) Cancer in endstage renal disease: potential factors involved. $\mathrm{Am} \mathrm{J} \mathrm{Ne-}$ phrol 18: 89-95.

Van der Torre HW, Dokkum WV, Schaafsma G, Wedel M, Ockhuizen T (1991) Effect of various levels of selenium in wheat and meat on blood Se status and on Se balance in Dutch men. Br J Nutr 65: 69-80.

Vanella A, Geremia E, Pinturo R, Tiriolo P, Liuzzo G, Tiriolo C, Custorella A, Condorelli G, Giglio A (1983) Superoxide dismutase activity and reduced glutathione content in erythrocytes of uremic patients on chronic dialysis. Acta Haematol 70: 312-315.
Vural A, Yilmaz MI, Calgar K, Aydin A, Sonmez A, Eyileten T, Acikel C, Gulec B, Kozak O, Oner K (2005) Assessment of oxidative stress in the early posttransplant period: Comparison of cyclosporine A and tacrolimusbased regiments. Am J Nephrol 25: 250-255.

Wastney M, Combs G, Patterson K, Veillon C, Levander O, Taylor P, Patterson B (2006) Selenium metabolism in humans: Linking biology and kinetics. In 8th Int Symp on Selenium in Biology and Medicine; University of Wisconsin, Madison, WI, USA, July 25-30, 2006, p 34.

Whitin JC, Tham DM, Bhamre S, Ornt DB, Scandling JD, Tune BM, Salvatierra O, Avissar N, Cohen HJ (1998) Plasma glutathione peroxidase and its relationship to renal proximal tubule function. Mol Genet Metab 65: 238-245.

Wlodarczyk Z, Zachara BA, Masztalerz M, Wasowicz W, Gromadzinska J (2003) Selenium, glutathione peroxidases and some other parameters in blood of patients after kidney transplantation. In 4th International Symposium on Trace Elements in Human: New Perspectives. Proceedings Book, part I. Pollet S, ed, pp 75-90, Athens, Greece.

Wlodarczyk Z, Zachara BA, Masztalerz M, Wasowicz W, Gromadzinska J (2005) Influence of selenium supplementation to renal allograft recipients on plasma glutathione peroxidase activity. Trace Elem Electrolytes 22: $16-22$.

Yang G, Zhou R, Yin S, Gu L, Yan B, Liu Y, Liu Y, Li X (1989) Studies of safe maximal daily dietary selenium intake in a seleniferous area in China. I. Selenium intake and tissue selenium levels of the inhabitants. $J$ Trace Elem Electrolytes Health Dis 3: 77-87.

Yoshimura S, Suemizu H, Nomoto Y, Sakai H, Katsuoka Y, Kawamura N, Moriuchi T (1996) Plasma glutathione peroxidase deficiency caused by renal dysfunction. $\mathrm{Ne}$ phron 73: 207-211.

Young IS, Woodside JV (2001) Antioxidants in health and disease. J Clin Pathol 54: 176-186.

Zachara BA (1992) Mammalian selenoproteins. J Trace Elem Electrolytes Health Dis 6: 137-151.

Zachara BA, Adamowicz A, Trafikowska U, Pilecki A (2000a) Decreased plasma glutathione peroxidase activity in uremic patients. Nephron 84: 278-279.

Zachara BA, Adamowicz A, Trafikowska U, Trafikowska A, Manitius J (2000b) Blood selenium and glutathione peroxidase activity in patients with different stages of chronic renal failure. In Mengen- und Spurenelemente. 20. Arbeitstagung 2000 Friedrich-Schiller-Universitat. (Anke $\mathrm{M}$ et al., eds) pp 940-947. Jena, Germany.

Zachara BA, Adamowicz A, Trafikowska U, Trafikowska A, Manitius J, Nartowicz E (2001a) Selenium and glutathione levels, and glutathione peroxidase activities in blood components of uremic patients on hemodialysis supplemented with selenium and treated with erythropoietin. J Trace Elem Med Biol 15: 201-208,

Zachara BA, Pawluk H, Bloch-Boguslawska E, Sliwka KM, Korenkiewicz J, Skok Z, Ryc K (2001b) Tissue level, distribution, and total body selenium content in healthy and diseased humans in Poland. Arch Environ Health 56: 461-466.

Zachara BA, Trafikowska U, Adamowicz A, Nartowicz E, Manitius J (2001c) Selenium, glutathione peroxidases, and some other parameters in blood of patients with chronic renal failure. J Trace Elem Med Biol 15: 161-166.

Zachara BA, Koterska D, Manitius J, Sadowski L, Dziedziczko A, Salak A, Wasowicz W (2004a) Selenium supplementation to patients with the end stage of chronic renal failure has no effect on the increase of lowered 
plasma glutathione peroxidase activity. Biol Trace Elem Res 97: 15-30.

Zachara BA, Salak A, Koterska D, Manitius J, Wasowicz W (2004b) Selenium and glutathione peroxidases in blood of patients with different stages of chronic renal failure. I Trace Elem Med Biol 17: 291-299.

Zachara BA, Wlodarczyk Z, Masztalerz M, Adamowicz A, Gromadzinska J, Wasowicz W (2004c) Selenium concentrations and glutathione peroxidase activities in blood of patients before and after allogenic kidney transplantation. Biol Trace Elem Res 97: 1-13.

Zachara BA, Wlodarczyk Z, Andruszkiewicz J, Gromadzinska J, Wasowicz W (2005) Glutathione and glutathione peroxidase activities in blood of patients in early stages following kidney transplantation. Renal Failure 27: 751755.

Zima T, Mestek O, Nemecek, Bartova V, Fialova F, Tesar $\mathrm{V}$, Suchanek M (1998) Trace elements in hemodialysis and continuous ambulatory peritoneal dialysis patients. Blood Purif 16: 253-260.

Zwolinska D, Grzeszczak W, Kilis-Pstrucinska K, Szprynger K, Szczepanska M (2004) Lipid peroxidation and antioxidant enzymes in children with chronic renal failure. Pediatr Nephrol 19: 888-892. 
